\title{
Morphological Variations of Peroneus Tertius: A Cadaveric Study with Anatomical and Clinical Consideration
}

\section{Peroneus Testiusun Morfolojik Çeşitliliği: Anatomik ve Klinik Anlayışla Bir Kadaverik Çalışma}

\section{Khizer Hussain Afroze $M \oplus$, Sangeeta Muralidharan $\odot$, J. Leonoline Ebenezer $\odot$, Sasirekha Muthusamy $\odot$}

Ethics Committee Approval: This study approved by the Institutional Ethic Committee of MV] Medical College \& Research Hospital, 10 August 2020.

Conflict of interest: The authors declare that they have no conflict of interest.

Funding: None.

Informed Consent: Not Applicable.
Cite as: Afroze MKH, Muralidharan S, Ebenezer JL, Muthusamy S. Morphological variations of peroneus tertius: A cadaveric study with anatomical and clinical consideration. Medeni Med J. 2020;35:324-9.

\begin{abstract}
Objective: The objective of this study was to highlight variations in the morphology of peroneus tertius muscle owing to its evolutional, academic, and clinical importance.

Methods: Sixty-six disarticulated lower limbs were used to study the morphological variations of peroneus tertius (PT) muscle like absence, duplication, accessory PT muscle, and abnormal site of origin and insertion. Detailed dissection was performed to study the proximal and distal attachments of PT muscle, and observed variations were recorded.

Results: Twelve out of 66 specimens showed the following variations, accessory and duplicate peroneus tertius was observed in one specimen (1.52\%) each. We categorized variations in insertions into six types. The most common variation in the present study was type II $(84.8 \%)$ followed by type VI (10.6\%). Type Ila and IV were observed in one specimen (1.52\%) each. Conclusion: The present study highlights variations in both origin and insertion of PT muscle . We have also postulated a new modified classification which is the first of its kind to highlight two new additional variations in insertions existing in the current literature. Awareness of the above variations would be useful to surgeons performing tendon transfers, tendoplasty, and resection surgeries of the foot.
\end{abstract}

Keywords: Fibularis tertius, accessory muscle, duplicate muscle, morphology, tendoplasty

öz

Amaç: Bu çalışmanın amacı, evrimsel, akademik ve klinik önemi nedeniyle peroneus tertius morfolojisindeki çeşitliliği vurgulamaktır.

Yöntem: Peroneus tertius (PT) kasının morfolojik çeşitliliğini incelemek için 66 disartiküle alt ekstremite kullanılmıştır; bulunmama, çift olma, yardımcı PT, anormal orijin ve yerleşim gibi çeşitlilikler kaydedilmiştir. PT'nin proksimal ve distal bağlantılarını incelemek için ayrıntılı diseksiyon yapılmıştır ve gözlenen çeşitlilikler kaydedilmiştir.

Bulgular: Altmış altı örnekten 12'si aşağıdaki çeşitleri göstermiştir, her bir örnekte (\%1,52) yardıma ve çift peroneus tertius gözlenmiştir. Eklentilerdeki çeşitliliģ̆i altı türe ayırdık. Bu çalışmada en yaygın olan, tip II $(\% 84,8)$ ve ardından tip VI $(\% 10,6)$ olmuştur. Her bir örnekte Tip IIa ve IV gözlenmiştir $(\% 1,52)$.

Sonuç: Bu çalışma, PT kasının hem orijindeki hem de eklentilerindeki çeşitliliği vurgulamaktadır. Ayrıca literatürde mevcut olanlara ek olarak, iki yeni eklenti çeşitliliğini vurgulamak için türünün ilk örneği olan yeni bir sınıflandırma önerdik. Yukarıdaki çeşitliliğin bilinmesi, tendon transferi, tendoplasti ve rezeksiyon ameliyatları gerçekleştiren cerrahlar için yararlı olacaktır.

Anahtar kelimeler: Fibularis tertius, yardımcı kas, çift kas, morfoloji, tendoplasti
Received: 28 November 2020

Accepted: 12 December 2020 Online First: 25 December 2020

Corresponding Author: MKH. Afroze

ORCID: 0000-0003-3790-302X MVJ Medical College and Research Hospital, Department of

Anatomy, Hoskote, Bangalore, India

drafroze.homoeo@gmail.com

S. Muralidharan

ORCID: 0000-0001-5109-1414

MVJ Medical College

Research Hospital, Department of

Anatomy, Bangalore,

Karnataka, India

J.L. Ebenezer

ORCID: 0000-0003-0381-6278

S. Muthusamy

ORCID: 0000-0001-5382-8571 ACS Medical College and Hospital, Department of Anatomy, Chennai, Tamilnadu, India 


\section{INTRODUCTION}

One of the unique evolutionary features of humans is the bipedal gait which has an intrinsic relation with arch of the foot. To ensure stability of the arch, certain phylogenetic changes have appeared in human foot, one of them being appearance of peroneus tertius muscle $(\mathrm{PT})^{1}$. It is regarded as the muscle of both extensor and peroneal compartments owing to its action as both dorsiflexor and evertor of the foot ${ }^{2}$.

Literature review is also suggestive of the fact that peroneus tertius is an exclusive feature in human and regarded as detached part of extensor digitorum longus (EDL) or migrated part of extensor digitorum brevis ${ }^{3,4}$.

Previous studies have acknowledged variations in the morphology of PT muscle ranging from absent PT muscle, additional slips from extensor digitorum longus, accessory PT muscle, and variations involving patterns of insertion ${ }^{3}$. These variations have been implicated in differential diagnosis of chronic ankle pain and in the pathogenesis of Jones fracture (stress fracture of the fifth metatarsal) ${ }^{4}$.

PT is a muscle of surgical interest as it has been extensively used in tendoplasty, tendon transfer, and resection of the foot ${ }^{4,5}$. Due to its evolutionary and clinical importance, we undertook this study

1. To highlight the incidence of morphological variations of PT.

2. To classify variations in insertion based on existing classification and to propose a new classification based on new variations encountered in our study.

\section{MATERIAL and METHODS}

This prospective study was carried out in the Department of Anatomy, MVJ Medical College and Research Hospital Bangalore over a period of five years. Sixty-six disarticulated lower limbs (38 right side, and 28 left side) irrespective of age and sex, retrieved from embalmed human cadavers of Caucasian origin were used to study the morphological variations of peroneus tertius (PT). The skin and subcutaneous tissue of the anterior compartments of leg, and the dorsum of the foot, thus exposing all the extensor tendons of foot. Detailed dissection was performed to study the proximal and distal attachments of PT muscle, and observed variations were recorded.

For statistical analysis, SPSS for Windows, version 16.0 (SPSS Inc., Chicago, Ill., USA) was used. Descriptive statistics including frequency and percentage were used to describe the categorical data.

\section{RESULTS}

Of the 66 lower limbs studied, variations of PT muscle were documented in 12 specimens (two variations in origin and 10 variations in insertion) accounted for $18 \%$ of the specimens. All the specimens showed the presence of PT. Variations were observed more so in the distal attachment than the proximal attachment of PT muscle. Variations of PT observed in the present study were as follows:

We observed two patterns of variation in the origin of PT muscle. In $1.52 \%$ of the cases dissected (one specimen), accessory PT was found arising from the shaft of fibula just distal to the normal origin of PT muscle. The muscle belly ran parallel to the belly of PT muscle and was seen getting inserted into the superior surface of talus (Figure 1). In one specimen (1.52\%), duplication of PT muscle was found, one of the PT muscle originated from distal one third of shaft of fibula as usual, whereas other PT muscle took origin from the tendon of EDL. The tendon of both PT muscles ran parallel to gain insertion into base of the fifth metatarsal (Figure 2).

Based on variations in the patterns of insertion of 


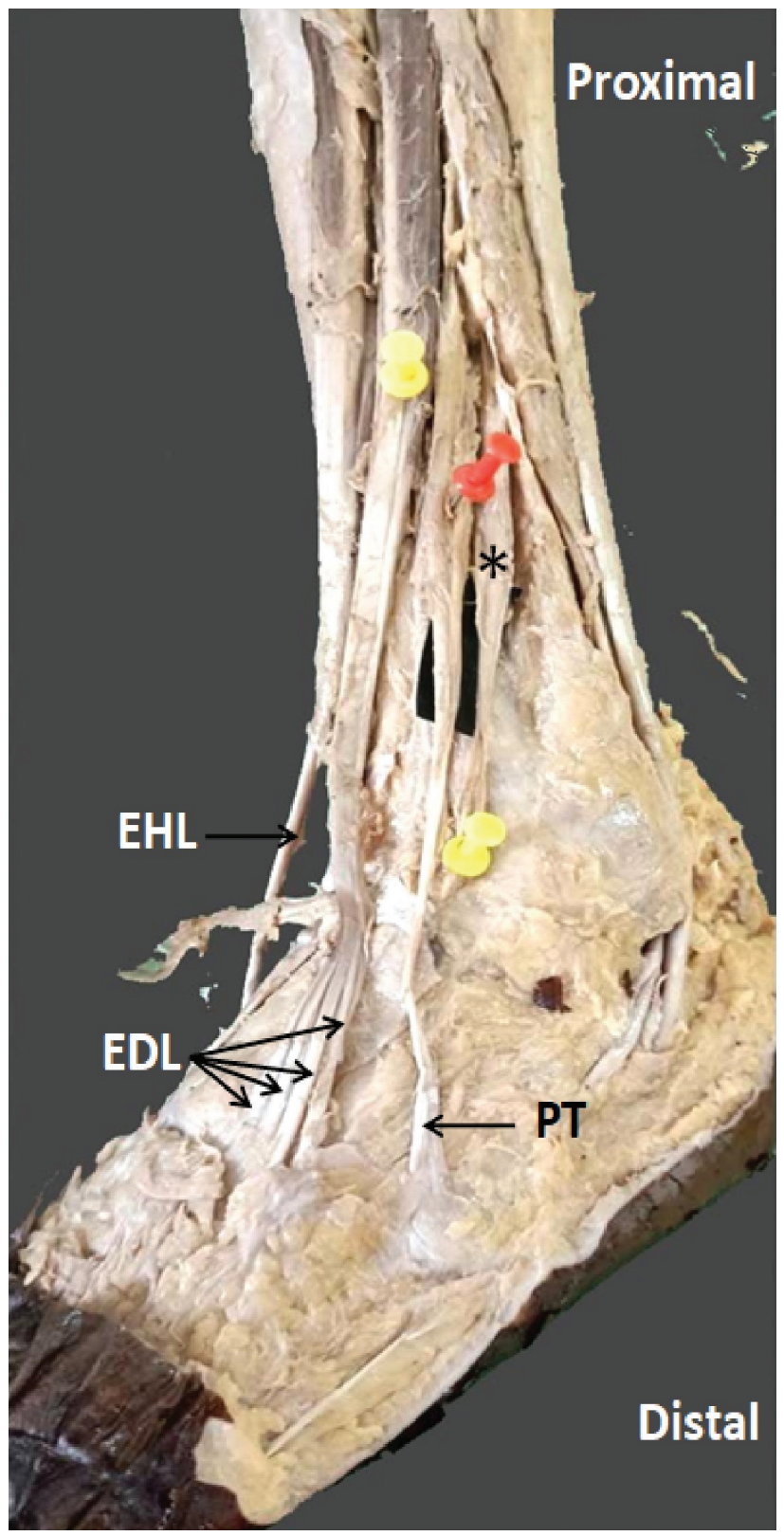

Figure 1: Showing accessory PT (*) arising from the shaft of fibula. EHL: Extensor hallucislongus, EDL: Extensor digitorum longus, PT: Peroneus tertius.

PT muscle observed in this study, we have proposed a new classification wherein the above encountered variations were broadly classified into six types. This new classification has been remodeled on the existing classification by Olewnik L. Type II in this classification confirms to the most commonly observed insertion of PT muscle which accounted for $84.8 \%(n=56)$ of all specimens.

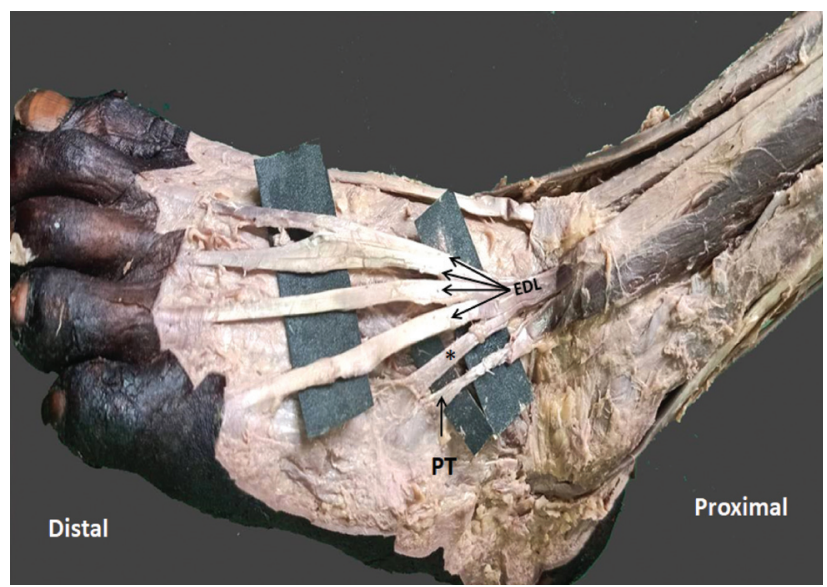

Figure 2: Showing duplicated PT (*) arising from EDL.

Table 1. Showing the incidence of variations in the pattern of insertion of PT based on laterality.

\begin{tabular}{llll}
\hline Type & Right $\mathbf{n}(\%)$ & Left n(\%) & Left n(\%) \\
\hline Type I & $0(0)$ & $0(0)$ & $0(0)$ \\
Type II & $31(81.6 \%)$ & $25(89.3 \%)$ & $25(89.3 \%)$ \\
TypeIIa & $1(2.6 \%)$ & $0(0.0 \%)$ & $0(0.0 \%)$ \\
Type III & $0(0)$ & $0(0)$ & $0(0)$ \\
Type IV & $1(2.6 \%)$ & $0(0.0 \%)$ & $0(0.0 \%)$ \\
Type V & $0(0)$ & $0(0)$ & $0(0)$ \\
TypeVa & $1(2.6 \%)$ & $0(0.0 \%)$ & $0(0.0 \%)$ \\
Type VI & $4(10.5 \%)$ & $3(10.7 \%)$ & $3(10.7 \%)$ \\
Total & $38(100.0 \%)$ & $28(100.0 \%)$ & $28(100.0 \%)$ \\
& & & \\
\hline
\end{tabular}

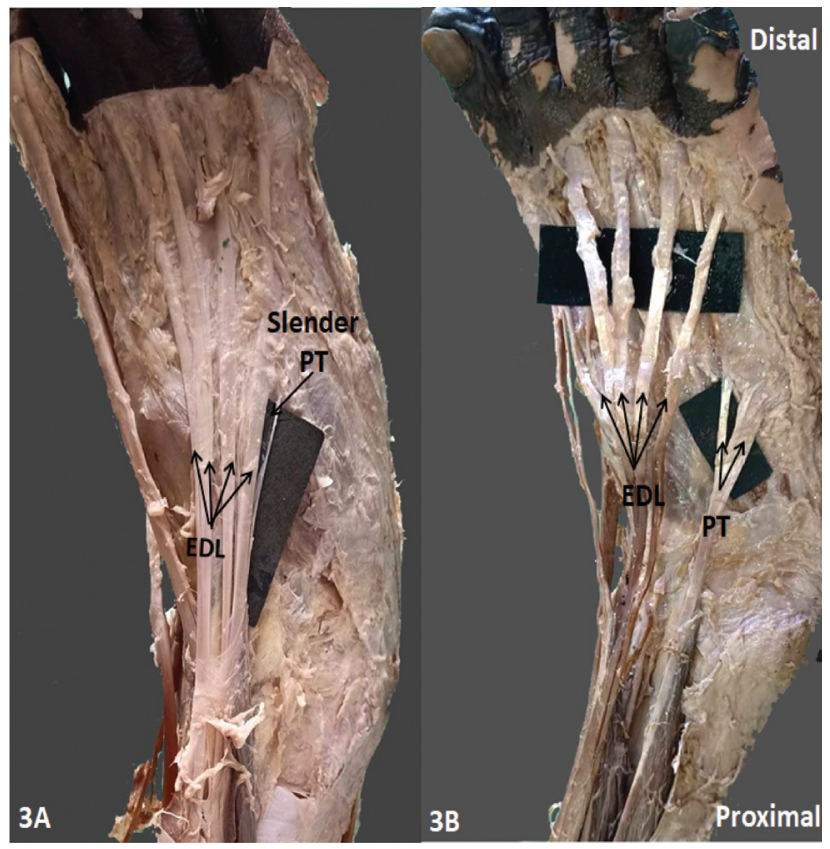

Figure 3A: Showing slender PT. 3B: Showing the distal end of PT dividing into medial and lateral slips.EDL: Extensor digitorumlongus, PT: Peroneus tertius. 
Table 1 shows the incidence of variations in the insertion pattern of PT muscle. In one (1.52\%) dissected specimen, it was observed that fleshy belly of PT muscle terminated in a very slender tendon much less than usual tendon caliber of PT muscle (Figure 3A). It was categorized as Type Ila.

In one (1.52\%) dissected specimen (Type IV), it was observed that the distal end of the PT muscle divided into medial and lateral slips. The medial slip was inserted into the dorsum of the shaft of the fifth metatarsal whereas lateral slip was inserted into the dorsal surface of base of the fifth metatarsal (Figure 3B).

In one $(1.52 \%)$ dissected specimen (Type Va), it was observed that the distal end of PT divided into medial and lateral slips. The lateral slip was inserted into the dorsal surface of the base of the fifth metatarsal whereas medial slip was seen interacting with the tendon of extensor digitorum brevis (EDB) of the middle toe (Figure 4A).

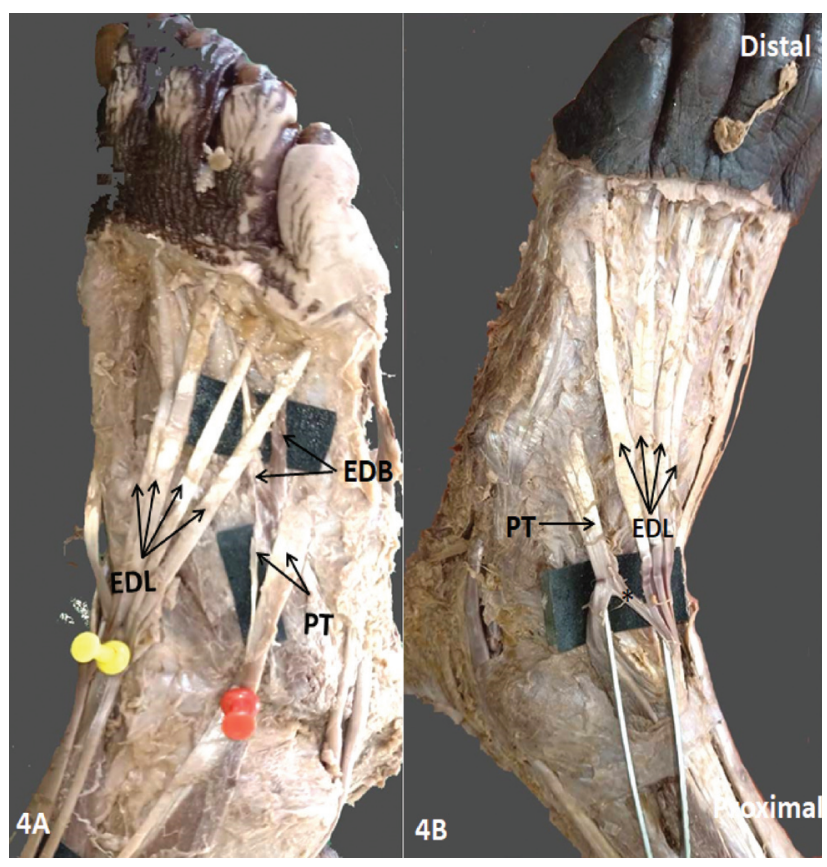

Figure 4A: Showing slips of PT communicating with EDB. EDB: Extensor digitorumbrevis.4B: showing anomalous tendinous slip (*) communicating EDL with distal PT. EDL: Extensor digitorumlongus, PT: Peroneus tertius, EDB: Extensor digitorum brevis.
In seven (10.6\%) dissected specimens (Type VI) anomalous tendinous slip branching proximally from extensor digitorum longus (EDL) to distal PT muscle was observed. The tendinous slip was seen intertwined with PT muscle at the bifurcation level of EDL tendons (Fig.4B).

\section{DISCUSSION}

There is a paucity of literature pertaining to classification of peroneus tertius muscle based on its origin and insertion. Two classifications based on its origin were postulated by Joshi et al. ${ }^{6}$ and Olewnik $^{7}$ and one classification based on the insertion of peroneus tertius was postulated by Olewnik. Novelty of this study lies in the fact that we have modified the classification of Olewnik. based on insertion of peroneus tertius muscle since we encountered a few new variations not falling under Olewnik classification.

Meta-analytic studies have revealed the prevalence of PT muscle ranging from $38.5 \%$ to $95.5 \%$ in Asian population. In our study, PT muscle was found to be present in all 66 lower limbs studied (100\%) which are in accordance with the study conducted by Nayak ${ }^{4}$.

Two different classifications were proposed by Joshi et al. and Olewnik respectively based on the origin of PT muscle. Joshi et al. ${ }^{6}$ classified origin of PT muscle based on its level of attachment in fibula as: 1 ; lower $3 / 4,2$; lower $1 / 2$, and 3 ; distal third (most commonly observed). According to Olewnik classification, Type 1-took origin from distal half of fibula, Type 2-distal third of fibula, Type 3-absent muscle belly, and independent tendon taking origin from tendon of $\mathrm{EDL}^{7}$.

Most commonly observed origin of PT muscle confirms to Type 3 classification of Joshi et al. ${ }^{6}$ and Type 2 classification of Olewnik ${ }^{7}$. The incidence of the same was observed as $96.97 \%$ (64 specimens) in our study. Two specimens showed varied origin in the form of accessory and duplicated PT muscle 
(Fig. 1 \& 2). The accessory PT muscle has not been reported in the literature before, however Mehta et al. $^{2}$ reported a case of additional head of PT muscle originating from EDL.

Olewnik proposed a classification based on the insertion of PT muscle into six types (Table 2$)^{7}$. In the present study, we categorized our variation based on the above classification. The most common variation in the present study was type II which accounts for $84.8 \%(n=56)$ of the specimens. Type IV was observed in one specimen (1.52\%) (Fig.3B).

A special morphological variant of insertion was observed in our study which cannot be directly categorized as per the above classification. In one specimen (1.52\%), we observed a slightly different variant of type II as the tendon of PT muscle in this specimen was extremely slender and therefore, we categorized it as Ila (Fig.3A).

In another specimen we observed distal end of PT

Table 2. The classification of Olewnik based on the insertion of PT into six types.

\begin{tabular}{ll}
\hline Type & Definition \\
\hline Type I & $\begin{array}{l}\text { Single insertion into the shaft of } 5^{\text {th }} \text { metatarsal } \\
\text { Type II } \\
\text { Type III }\end{array}$ \\
$\begin{array}{l}\text { Single insertion into the base of the } 5^{\text {th }} \text { metatarsal } \\
\text { tarsal insertion into the base of } 4^{\text {th }} \text { and } 5^{\text {th }} \text { meta- }\end{array}$ \\
Type IV & $\begin{array}{l}\text { Split insertion, one of which inserted into the base } \\
\text { and other into shaft of } 5^{\text {th }} \text { metatarsal }\end{array}$ \\
Type V & $\begin{array}{l}\text { Split insertion, one to base of } 4 \text { th and other to the } \\
5^{\text {th }} \text { metatarsal }\end{array}$ \\
Type VI & $\begin{array}{l}\text { Communicating with peroneus brevis }(\mathrm{PB}) \text { or Ex- } \\
\text { tensor digitorum longus (EDL). }\end{array}$
\end{tabular}

Table 3. Comparison of observed variations of PT with the study by Olewnik.

\begin{tabular}{lll}
\hline Type & Olewnik $^{\mathbf{7}} \mathbf{n}(\%)$ & Current Study n (\%) \\
\hline Type I & $41(45 \%)$ & $0(0)$ \\
Type II & $20(22 \%)$ & $56(84.8 \%)$ \\
Typella & $0(0)$ & $1(1.5 \%)$ \\
Type III & $15(16.5 \%)$ & $0(0)$ \\
Type IV & $8(8.8 \%)$ & $1(1.5 \%)$ \\
Type V & $5(5.5 \%)$ & $0(0)$ \\
TypeVa & $0(0)$ & $1(1.5 \%)$ \\
Type VI & $2(2.2 \%)$ & $7(10.6 \%)$ \\
& & \\
\hline
\end{tabular}

muscle dividing into medial and lateral slips. The lateral slip was inserted into the dorsal surface of base of the fifth metatarsal whereas medial slip was seen intertwined with the tendon of extensor digitorum brevis (EDB) of the middle toe (Figure 4A). This is a slight variant of Type V of Olewnik ${ }^{7}$ classification where medial slip was getting inserted into base of the fourth metatarsal whereas in our study, it interacted with the tendon of EDB for the middle toe. Hence, we categorized this variant as Type Va.

No incidence of Type I or Type III was observed in the present study. A case report of anomalous insertion of PT muscle was reported by Abhinitha et al. ${ }^{8}$. They observed distal end PT muscle dividing into medial and lateral slips. Lateral slip getting inserted into base of the fourth metatarsal and medial slip continuing as dorsal digital expansion (Table 3).

Yammine and Eric conducted an extensive review of literature and stated that in more than $95 \%$ of the cases, absence of PT muscle was associated with accessory fibular muscles ${ }^{9}$. Same findings were substantiated by Johnson and Macalister ${ }^{10-}$ 12. Findings of our study however contradicts with this finding, as we encountered presence of both PT with an accessory PT.

A few authors reported the duplication of PT muscle ranging from one to three percent ${ }^{12,13}$. The incidence reported in our study in accordance with the above studies. Surekha DJ et al. ${ }^{13}$ reported the duplicated tendon of PT muscle arising from EDL and getting inserted into the fourth metatarsal but in contrary, present study shows the insertion of duplicated tendon of PT muscle into the base of the fifth metatarsal (Fig. 2).

The muscles of lower limb develop from hind limb bud (lumbar and sacral somites) whereas tendons develop from somotopleuric mesoderm. The myogenic cells differentiate into myoblasts which further divide and subdivide to get attached to 
the developing lower limb bones to form final muscles. The disturbance in mechanisms governing these divisions may result in morphological variations ${ }^{1}$.

Eversion is a typical feature of human locomotion assisted by PT muscle, and in the absence of which, peroneus longus and brevis muscles take over similar function. The frequency of PT has an underlined genetic basis, for which further studies need to be conducted across populations to validate the same? . The presence of PT muscle may be detrimental in the recovery phase of the John's fracture because of twisting force exerted on the base of the fifth metatarsal ${ }^{14,15}$.

Limitation of the study: Since this study was done on disarticulated lower limbs; we could not gather data on age and gender. Sample size is also a limitation owing to the fact that the study was done on cadavers. Further studies with large sample size need to be carried out to validate our results.

\section{CONCLUSION}

To conclude, we came across with very few studies on Indian population (especially South Indian), which prompted us to undertake the study and to highlight variations of PT muscle from academic and clinical point of view. The present study highlights variations in both origin and insertion of PT muscle. We also postulated a new modified classification which is the first of kind to highlight two new additional variations in insertions different from those cited in the current literature.

\section{REFERENCES}

1. Jana R, Roy TS. Variant insertion of the fibularis tertius muscle is an evidence of the progressive evolutionary adaptation for the bipedal gait. Clin Pract. 2011;1:e81. [CrossRef]

2. Mehta V, Gupta V, Nayyar A, et al. Accessory muscle belly of peroneus tertius in the leg--a rare anatomical variation with clinical relevance--utility in reconstructions. Morphologie. 2011;95:23-5. [CrossRef]

3. Ughade JM, Kardile PB. Anatomical study of Peroneus tertius. Sch J App Med Sci. 2018;6:3116-8.

4. Nayak G. A Morphometric Analysis of Fibularis Tertius Muscle in Eastern Indian Population. Int J Anat Radiol Surg. 2017;6:AO23-5.

5. Witvrouw E, Borre KV, Willems TM, Huysmans J, Broos E, De Clercq D. The significance of peroneus tertius muscle in ankle injuries: a prospective study. Am J Sports Med. 2006;34:1159-63. [CrossRef]

6. Joshi SD, Joshi SS, Athavale SA. Morphology of peroneus tertius muscle. Clin Anat. 2006;19:611-4. [CrossRef]

7. Olewnik Ł. Fibularis Tertius: Anatomical Study and Review of the Literature. Clin Anat. 2019;32:1082-93. [CrossRef]

8. Abhinitha P, Rao M, Rao A, Nayak BS, Shetty S. Anomalous Pattern of Tendinous Slips of Peroneus Tertius and Extensor Digitorum Longus Muscles in the Foot-A Clinically Important Variation. Gulhane Medical Journal. 2014;56:179-81. [CrossRef]

9. Yammine K, Eri冈 M. The Fibularis (Peroneus) Tertius Muscle in Humans: A Meta-Analysis of Anatomical Studies with Clinical and Evolutionary Implications. Biomed Res Int. 2017;2017:6021707. [CrossRef]

10. Johnson DC. Tendon Variations of the PeronealMusculature in Man, [Ph.D. thesis], Yale Medical Library, 1973.

11. Macalister A. Additional observations on muscular anomalies in human anatomy (third series), with a catalogue of the principal muscular variations hitherto published. Transactions of the Royal Irish Academy, Dublin. 1872;25:1-134.

12. Macalister A. Further notes on muscular anomalies in human anatomy, and their bearing upon homotypicalmycology, Royal Irish Academy. Dublin. 1867;20:121-64.

13. Jadkov SD, Amboli MP, Patil RR, Doshi MA, Roy P. Fibularis Tertius Muscle: Cadaveric Study in Indians. JKIMSU. 2015;4:64-9.

14. Vieira AF, Monteiro ACS, Nacur FOM, Coutinho R, Direito TX, Torres DFM. Prevalence and Topography of the Peroneus tertius Muscle: a Study of Human Cadavers. J Morphol Sci. 2018;35:106-9. [CrossRef]

15. Vertullo CJ, Glisson RR, Nunley JA. Torsional strains in the proximal fifth metatarsal: implications for Jones and stress fracture management. Foot Ankle Int. 2004;25(9):650-6. [CrossRef] 